\title{
An explanation of the occupational structure of sectors of industry
}

Citation for published version (APA):

Dekker, R., de Grip, A., \& Heijke, J. A. M. (1988). An explanation of the occupational structure of sectors of industry. Researchcentrum voor Onderwijs en Arbeidsmarkt, Faculteit der Economische Wetenschappen. ROA Working Papers No. 2E https://doi.org/10.26481/umarow.198802E

Document status and date:

Published: 01/01/1988

DOI:

10.26481/umarow.198802E

Document Version:

Publisher's PDF, also known as Version of record

\section{Please check the document version of this publication:}

- A submitted manuscript is the version of the article upon submission and before peer-review. There can be important differences between the submitted version and the official published version of record.

People interested in the research are advised to contact the author for the final version of the publication, or visit the DOI to the publisher's website.

- The final author version and the galley proof are versions of the publication after peer review.

- The final published version features the final layout of the paper including the volume, issue and page numbers.

Link to publication

\footnotetext{
General rights rights.

- You may freely distribute the URL identifying the publication in the public portal. please follow below link for the End User Agreement:

www.umlib.nl/taverne-license

Take down policy

If you believe that this document breaches copyright please contact us at:

repository@maastrichtuniversity.nl

providing details and we will investigate your claim.
}

Copyright and moral rights for the publications made accessible in the public portal are retained by the authors and/or other copyright owners and it is a condition of accessing publications that users recognise and abide by the legal requirements associated with these

- Users may download and print one copy of any publication from the public portal for the purpose of private study or research.

- You may not further distribute the material or use it for any profit-making activity or commercial gain

If the publication is distributed under the terms of Article $25 \mathrm{fa}$ of the Dutch Copyright Act, indicated by the "Taverne" license above, 
AN EXPLANATION OF THE OCCUPATIONAL

STRUCTURE OF SECTORS OF INDUSTRY

ROA-W-1988/2E

R.J.P. Dekker, A. de Grip, J.A.M. Heijke

RESEARCH CENTRE FOR EDUCATION AND LABOUR MARKET

Faculty of Economic Sciences

Rijksuniversiteit Limburg

Maastricht, October 1988 
AN EXPLANATION OF THE OCCUPATIONAL

STRUCTURE OF SECTORS OF INDUSTRY

\section{ROA-W-1988/2E}

R.J.P. Dekker, A. de Grip, J.A.M. Heijke

RESEARCH CENTRE FOR EDUCATION AND LABOUR MARKET

Faculty of Economic Sciences

Rijksuniversiteit Limburg

Maastricht, October 1988 
Page

SUMMARY

2. THE OCCUPATION MODEL

2.2. Factors suggested for the development of the occupational structure

2.3. Specification of the explanatory variables

3. ECONOMETRIC MODELLING 9

3.1. Derivation of the equation to be estimated 9

3.2. Model choice 12

4. ESTIMATION RESULTS 14

4.1. Overall results 14

4.2. Discussion of the results on the level of occupational sectors

5. CONCLUSIONS AND SUGGESTIONS FOR FURTHER RESEARCH 21

LITERATURE

ANNEX I : List of occupation codes and corresponding names 26

ANNEX II : Division of sectors of activity and sources of variables 30

ANNEX III: Differences between adjusted $R^{2}$ for the chosen model and the sector-dummy model 32

ANNEX IV : Estimation results 33 
SUMMARY

This study sets out to disclose the factors underlying the development of the occupational pattern. The investigation is one link towards the construction of the education/labour-market information system that is being evolved by the ROA. The shares of occupational classes in each economic sector are taken as points of departure. The explanatory variables are technological progress and cyclical and structural sectoral developments. For each occupational class, an estimation is made with the help of a linear model, the estimation method being that of Weighted Least Squares. To permit several variables to be included in the equation, the data have been pooled over sectors and time. In two fifths of all cases, a model with explanatory variables has been chosen; in the remaining instances a sectordummy model was found to suffice. 
ACKNOWLEDGEMENT

The study has been carried out as part of a long-range research project commissioned by the Ministry of Education and Sciences. The objective of the project is to develop an education/labour-market information system to help secondary and university students choose the right type of school and/or occupation (ROA 1988).

The investigation reported on here represents an intermediary step towards the construction of the education/labour-market information system. Its specific purpose is to extend and improve the occupation model. At a later stage, attention will be paid to the modelling of training patterns.

The investigation was carried out under the direction of Professor J.A.M. Heijke, director of the ROA, by Drs R.J.P. Dekker, with regular feedback to Dr A. de Grip. Thanks are due to Drs L.F.M. Groot for his contribution to the discussions. The undergraduate assistants G. Kloek and M.H. Wieling were helpful in collecting data and processing the estimation results. 


\section{INTRODUCTION}

This report describes the construction of an explanatory model intended to explain the share of each occupation in the total employment of sectors of activity. The model is meant as a first step towards later medium-term forecasts of employment by occupation. Such forecasts will be an important element of the education/labour-market information system being developed by the ROA ${ }^{1}$. The present report concentrates on developing an explanatory model, only the occupational pattern being taken into account. At a later stage, a similar attempt will be made to develop a model referring to the educational pattern of individual occupations.

Hopefully, information about the medium-term development of employment in occupational categories may help achieve a closer match between educational facilities and the demands of the labour market, because it may enable those faced with a choice of study branches to take account of the expected employment prospects for different occupations by the time they are completing their studies.

In the United States, the Bureau of Labor Statistics issues a forecast of the medium-term labour-market developments every two years. The system used to that end distinguishes five steps. The fourth step, for instance, is to derive employment by sector from forecasts of the macro-economic development by means of regression analysis and trend extrapolation. The results are used as input at the final stage to determine the occupational pattern by sector. Sectoral employment is distributed among occupations on the basis of information obtained by industrial surveys. In drawing up the forecasts, a correction is carried through for a number of economic factors, among which technological progress. In Western Germany, labour-market forecasts are drawn up by commission of the 'Institut für Arbeitsmarkt- und Berufsforschung (IAB)'. There, too, production by sector is derived by the extrapolation of trends obtained from forecasts of macro-economic development. The next step is the breakdown into productivity and job opportunities. The latter are distributed among qualification areas based on occupational and training characteristics. The method used is the so-called manpower approach.

1. Heijke (1986), and ROA (1988). 
In the Netherlands, various forecasts of employment by occupation have been drawn up in the past few years. The ANTOS study (1984), for instance, was undertaken to verify whether the shares of 30 occupational categories in total employment by sector showed a trend-wise development. In the NEI study (1986), first employment by sector was determined from a number of macroeconomic variables, and next a forecast by occupation made with the help of a distribution model including a trend term. The drawback of both investigations is, however, that the forecasts were based on time-series which included only a small number of observations. The ROA, too (De Grip, Heijke, Dekker and Groot, 1987), has attempted an occupational forecast with the help of a distribution model. That analysis, too, had to be limited to an univariate distribution model on account of the small number of observations. The SEO (Teulings, Koopmans, Koopmanschap and Vedder, 1987) tried to overcome that drawback by using a model which pooled the data over sectors and time. However, that model contains no more than a trend variable either. The outcomes of such a trend model cannot be interpreted in economic terms; moreover, a trend always presupposes that a given occupation has the same development tendency through all sectors.

The occupation model constructed in the present study pools the observations over sectors and through time. Besides, an attempt has been made at an explanatory model capable of describing shifts in the occupational pattern of sectoral employment. In such an approach fits a multivariate model; moreover its results are easier to interpret than those of trend extrapolations. The new model accommodates several factors supposed to influence the occupational pattern. Pooling increases the number of degrees of freedom of the equations to be estimated, which renders the estimations more accurate.

The report is organized as follows. Chapter 2 presents the occupation model, the first section explaining the model's principles, and the second describing the economic factors. The corresponding variables are specified in section 2.3. In the first section of chapter 3 the model equation is derived; section 3.2 indicates by what criteria one out of several model variants was preferred. Chapter 4 discusses the research results. Section 4.1 presents the overall results; section 4.2 discusses them by occupational category. Chapter 5, finally, presents the main conclusions with respect to the analytic model employed in this study. Some suggestions are made for the continuation of the present line of research. 


\section{THE OCCUPATION MODEL}

\subsection{Introduction}

The model was constructed on the assumption that the occupational pattern is in fact determined by the demand side of the labour market. Sectors try for an optimum functional or occupational pattern to make production as efficient as possible. With a view to visualizing the demand side, we have derived from economic theory the factors that influence the occupational pattern.

The share of an occupation in a sector's employment has in each instance been taken as explanatory variable. That choice has been made in direct consequence of the objective that had been set for the investigation -to investigate the occupational pattern- and the consideration that the later forecasts will be based on sectoral forecasts made by the CPB (see also De Grip, Heijke, Dekker and Groot, 1987). If the occupational shares in sectoral employment can be predicted on that basis, a forecast of employment by occupation can be derived from them. The occupations have been arranged into 83 occupational classes. The division into 24 sectors of activity used by the CPB in the CEP ${ }^{2}$ has been the basis for our sectoral division; the number of sectors distinguished has been reduced to 21 by combining the food sectors (cattle-farm produce, other products, and tobacco and beverages) as well as the construction and home-owning sectors. Government has been added as a separate 'industrial' sector. For a list of occupations and sectors, please consult the annexes 1 and 2 .

\subsection{Factors suggested for the development of the occupational structure}

This section will first discuss the factors likely to explain the occupational pattern, and next develop variables for each factor. The (relative) wage costs are one possible explanation. When the wage costs in an occupational class rise too high, that occupation prices itself out of the market, and substitutes will be looked for. An organizational change may ensue in the sense that the occupational category in question is replaced with

2. See, for instance, the Central Economic Plan for 1987, table D3, page 294 . 
another or with capital investment. For lack of adequate data about wage costs, we shall assume in this report either that the wage structure as such does not change, or that the influence of the wage structure is constant. But even if we had adequate wage data, to include them at this exploratory stage of modelling might be premature. Actually, as wages are an endogenous factor of the demand as well as the supply side, their inclusion would tend to make the model cumbersome to formulate and estimate.

The shares of the occupations in the public sector have been left out of account, because of the specific nature of employment growth in that sector. various government occupations depend on the financial scope of the government and on specific demographic developments (number of young and older people). Moreover, to collect data on, for instance, value added or investments of the public sector, is especially difficult.

The omission of occupations in the public sector has been one reason to leave the effect of demographic factors on the occupational pattern out of account. That effect is particularly manifest in the highly specific occupations frequent in education and health care. The demand for education or medical care may change with the population structure, but for accurate estimation not only the population structure must be known but also complementary data on the intensity of use among given population groups. Moreover, the occupations in the sphere of personal care have already been studied by the Social and Cultural Planning Bureau (CPB/SCP, 1984), and the demand for teachers by the NEI (1986).

The present study concentrates on the following factors presumably affecting the occupational pattern:

1. Technological developments.

2. Sector-specific cyclical effects.

3. Sector-specific structural factors.

To 1. There is no consensus in the literature about how technological advance works out on the occupational pattern ${ }^{3}$. Three trains of thought can be distinguished. The first assumes a rising share of the specialists and managers, and a corresponding rise of the proportion of well educated in

3. Reference is made to K.I. Spenner, 1985, for a survey. 
total employment. The reason for that upgrading is that new abilities, more responsibility, and the capacity to work in a changing environment are required. Adherents of the 'downgrading' school on the other hand stress that with technological progress, activities rather tend to become simpler, so that the shares of the categories mentioned above in sectoral employment will decrease. In the third vision, technological advance entails contrary effects which may cancel each other out. The total effect will depend on the stage of technological development. At the beginning stage, there is a demand for higher-trained staff (upgrading), while at a later stage the work will once more become routine (downgrading). Furthermore, the environment of the industry and the way companies respond to changes are important determinants of the influence of technological progress on the occupational pattern.

To 2. The occupational pattern can also be affected by the degree to which a sector's sales are subject to cyclical fluctuations. If we split the labour market into a primary segment, comprising the permanent jobs with relatively high wages, and a secondary one with temporary jobs, poor working conditions, etc., cyclical fluctuations are expected to be strongest for the occupations on the secondary market, which are marked by high labour mobility (Soeringer and Piore, 1971; De Grip, 1985). On the primary labour market, indeed, 'labour hoarding' will be more frequent (De Koning, 1987), companies adapting their employment only to a limited degree to reduced sales prospects. The reasons can be: legal stipulations, transaction costs (recruitment and dismissal), training costs, the company's reputation, technical and organizational limitations because of the division of tasks and the overhead labour (labour corresponding only indirectly and discontinualiy to the output), uncertainty about sales prospects, and the imperfect functioning of the labour market.

To 3. Besides cyclical fluctuations, a sector's structural development can determine the occupational pattern. One phenomenon that comes to mind is that small companies combine more functions in one person. Others are the disappearance of the smaller companies from a sector, only the larger ones remaining, and the tendency for companies to include in their own production scheme activities that used to be carried out outside the sector. The larger sectors are also more apt to initiate occupational training courses ${ }^{4}$. The

4. Den Hartog and Thoolen, CPB (1971). 
rise of countries with far cheaper labour, and the simultaneous tendency towards knowledge-intensive products in the Netherlands, are also relevant factors. Because such processes are long-winded, they may delay in finding expression in employment mutations within sectors. A trend variable might be used to visualize such developments. However, because the evolution through time need not be the same for all sectors, other variables corresponding to these possible causes have been looked for.

\subsection{Specification of the explanatory variables}

We have tried to establish quantifiable variables to represent the factors referred to above. Because the variable to be explained derives from the CBS Labour-Force Censuses (LFC), held every two years during the 1975-1985 period, the explanatory variables should in principle be available for the same observation years as well as on the sectoral and occupational levels used by $u s^{5}$. Since the regressand (the occupational share) is a relative quantity, the logical thing is to express the regressors in relative quantities as well, for otherwise the sectors in which a given regressor assumes high absolute values would have too great an influence in the estimation of the parameters.

To measure the structural component of sectoral developments, two variables have been constructed. They measure the effect of scale enlargement of production or service. $\begin{aligned} \operatorname{WPAVE}(s, t)= & \text { Average number of workers (per company) in the sector in } \\ & \text { question at time } t^{6} \text {. }\end{aligned}$

$\operatorname{VAAVE}(s, t)=$ Average value added (per company) in the sector.

These variables show a broken curve of data, however. After 1977, the measuring of the number of companies was changed, which makes it difficult to construct consistent time series. We have tried to compensate that deficiency by introducing an annual dummy (for 1975 and 1977). However, as in the estimation of the equations we came up against multicollinearity

5. A few exceptions are given in annex 2 .

6 . For the sources, see annex 2. 
between the annual dumy and the sectoral constants, we decided not to include these variables in the model equation.

To include the structural component in the model nevertheless, we have introduced a trend term $\tau(=1,2, \ldots, 6)$, measuring in addition the influence of other (macro-economic) variables that are hard to make explicit.

We shall now discuss the possible reasons for changes in the occupational pattern that are included in the model.

The technological progress embodied in physical capital goods is represented by the investments in equipment, transport, and works of civil engineering. What matters is the structural effect of investments; we assume that the older investments have relatively little influence on the occupational pattern. With a view to including the investment level in the model, the variable INVVA has been constructed; it relates for each sector the investments made in the past five years to the value added of the past five years.

$\left.\operatorname{INVVA}(s, t)=\sum_{j=-4}^{0} \operatorname{INV}(s, t+j)\right] / \underset{j=-4}{\left[\sum_{j=1} \operatorname{VA}(s, t+j)\right]}$

$\operatorname{INV}(s, t)=$ investments in sector $s$ in year $t$

$\operatorname{VA}(s, t)=$ value added.

The degree of automation of the production or service is a specific feature of the technological innovation that is not sufficiently expressed by the level of investments. The influence of automation is measured by the proportion of automation experts in the total number of people employed by a sector.

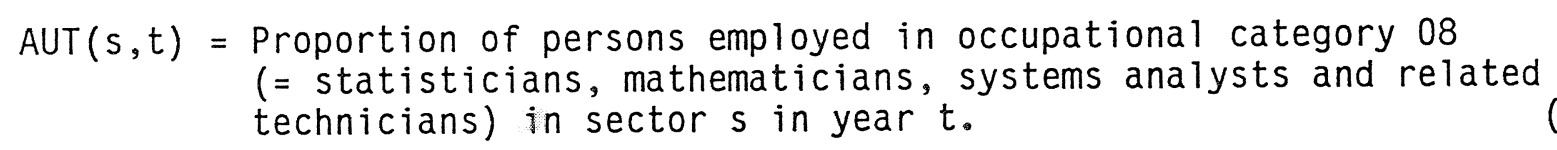

The inclusion of an occupational share as regressor suggests passing to a simultaneous model describing separately the occupational shares and the proportion of automation experts. But in our specific case the disturbance terms among occupations are assumed independent. Moreover, the exogenous 
variables are the same in both equations, so that the equations (the automation experts and the other occupations) can be estimated separately by ordinary least squares $(\mathrm{OLS})^{7}$.

The best way to define sector-specific structural effects is by the fluctuations in the sector's degree of capacity utilization. To that end, the actual production in the year concerned is related to the production capacity available. That variable is difficult to construct, however, because there are troubles with the establishment of a sector's capacity. The solution has been found in a variable supposed to fluctuate in positive proportion with the degree of capacity utilization, namely, value added in the year in question in relation to the five-yearly progressive average of value added.

$$
\operatorname{DCU}(s, t)=V A(s, t) /\left[(1 / 5) \sum_{j=-2}^{2} V A(s, t+j)\right]
$$

7. See Judge et al. (1982), chapter 12. 


\section{ECONOMETRIC MODELLING}

\subsection{Derivation of the equation to be estimated}

For each occupation an equation is drawn up, data being pooled over sectors and time. That approach implies the equal response to exogenous impulses of an occupation's employment share in all sectors in which that occupation occurs. The economic sectors have been classified in two main sectors, namely agriculture and manufacturing on the one hand and the service sectors. on the other ${ }^{8}$. Separate estimations have been made for each main sector. We could extend the pooling across all sectors, but that would impose the same structure, that is to say, the same parameters, on both two main sectors. Admittedly estimation would be more efficient (with narrower variances of the estimated parameters). On the other hand if pooling across the board is not strictly permissible, specification errors will occur in the model. Now the danger of specification errors is more serious than the loss of efficiency, and therefore separate pooling for each main sector has been preferred. In concrete terms this implies that the parameters may differ between the main sectors.

In this report, we have abandoned the idea of a choice model ${ }^{9}$. While in the linear probability model the shares do add up to 1 , there is no guarantee of the shares themselves lying between 0 and 1 . The probit and logit methods are out because three quarters of the cells of the share matrix from sector to occupational class are empty. Pooling of the data could lead to their being estimated at over 0 , which would imply the introduction of entirely new and perhaps irrelevant occupations into a sector. To estimate a logit model under side restrictions was not feasible because of the large number of restrictions in combination with the pooling. Moreover, in this exploration, to keep open the possibility of verifying the binding quality of the restrictions is recommendable. In addition, our approach makes for better interpretation of the parameters. Indeed, a choice model requires choosing one single occupation as numerical value, which crosses prohibits statements about the parameter values.

8. For the distribution of sectors among main sectors, reference is made to annex 3.

9. See, among others, Judge et a1. (1985), chapter 18. 
Besides choice models, which on certain assumptions have the maximization of utility as economic background, the so-called distribution model ${ }^{10}$ is found in comparable studies of employment. The distribution model has no economic background; the specification is based on statistics (shares lie between 0 and 1 and add up to 1 ). Moreover, such models require the choice of a reference occupation, which makes the interpretation of the parameters less clear.

With the choice models as well as the distribution model, pooling over sectors and time implies that the specification is the same for all occupations. One objective of the present study is to check whether that assumption is warranted. For that reason a multiplicative model based on the least-squares method was preferred, with correction only for heteroscedasticity. In the future, we will try to find a direct way to include the restriction on the shares in the model. More attention is also envisaged for the structure of the disturbance term and for the question whether a dynamic approach could improve the model.

$Y(b s t)=a(b s) \cdot \prod_{k}\left\{X[k](b s t)^{\beta[k](b)}\right\} \cdot \exp [\tau(b) \cdot t] \cdot P A(b s t) \cdot \exp [\epsilon(b s t)]$

$b, s, t$ : Occupation index, sector index, and time index, respectively.

$Y$ : Share of persons employed in the occupation in question in the sector's total employment.

$X$ : Matrix of explanatory variables (exclusive of the trendvariable).

$t$ : The trend term.

PA: The persons/workyears ratio.

$\epsilon \quad$ : Disturbance term, with normal distribution $N(0, \Sigma)$, with $\Sigma=$ $\sigma^{2} D$, $D$ being a diagonal matrix: $D\left(\right.$ bst, $\left.b^{\prime} s^{\prime} t^{\prime}\right)\left\langle>0\right.$ if $b=b^{\prime}$, $s=s^{\prime}, t=t^{\prime}$.

$\alpha, \beta, \tau:$ Parameters.

In this model, the $\beta$-vector can be interpreted as the elasticity of $Y$ to $X$ (the elasticities being constant). The trend term is included exponential$1 y$, because to interpret a trend $\tau$ as an elasticity is not a good idea. In the above specification, the trend parameter can be looked upon as a growth rate. Caution is needed when $\tau$ has a high value, because in that case an occupation's share in a sector may 'explode'.

10. See Leser (1941-42). 
The $C P B$ uses the $P / A$ ratio in its medium-term estimations to transform workyears into persons employed ${ }^{11}$. As an indicator of the $P / A$ ratio, the reciprocal of the part-time variable is taken, defined as follows.

$\operatorname{PTF}(b, s, t)=\sum_{u}[W P(b, u, t) * W T(u)] / \sum_{u}[W P(s, u, t) * W T(u)]$

$W P(b, s, t)$ : number of persons engaged in occupation class $b$ and hours class $u$ at time t.

$W P(s, u, t)$ : the analogous term for the sector.

WT (u) : the number of hours (or the median of the hours class). For classes of 40 or more hours, the class median has been set at 40 hours, on the consideration that a person working more than 40 hours does not normally occupy more than one employment position.

The result is an approximation because the normal full worktime in the occupation has been set equal to the normal full worktime in the sector (the two cancelling each other out), and because part-time work in the occupation in the sector has been replaced with overall part-time work in the occupation. In equation 7, properly PTF[bs]/PTF[s] should be measured, but only PTF[b]/PTF[s] is known. The approximation is closer as the number of persons engaged in occupation $b$ in sector $s$, (WP[bs]) is greater.

To estimate the parameters, we take the logarithm of the left- and righthand terms of equation 6, and transfer the P/A-variable to the left (replacing it with the PTF-variable).

$$
\begin{aligned}
y=a^{*}(b s)+\beta(b)^{\prime} \ln \{X(b s t)\}+\tau(b) \cdot t+\epsilon(b s t) \\
\text { with } \begin{aligned}
y & =\ln \{Y(b s t)\}+\ln \{P T F(b s t)\} \\
\beta^{\prime} \ln \{X\} & =\sum_{k} \beta[k] \cdot \ln \{X[k]\} \\
a^{*} & =\ln (a)
\end{aligned}
\end{aligned}
$$

Equation 8 is estimated by the method of weighted least squares (WLS), the weight being the number of persons engaged in the occupation within the sector, WP[bs]. The reason is that the regressand approximates the population values better as more persons are engaged in an occupation within a

11. For the explanation of these concepts, see W. Bos (1987). 
sector; that is to say, the sample error becomes relatively smaller. Estimation by WLS has an additional advantage. The values of all the shares are very near to 0 and logarithmical transformation extends the smallest shares most, which is best prevented because small shares (as far as corresponding to small numbers) are less important than larger shares. So, we want to prevent small numbers of employed persons determining the structure which applies also to sectors representing large numbers of employed persons.

\subsection{Model choice}

Only for occupations that occur in two or more sectors of a main sector have a number of nested models been estimated to find out what factors influence the occupational shares in the sectors. That restriction was needed because otherwise there would be too few observations for multivariate regression. The shares of occupation not satisfying that restriction will be established in another manner. The same holds for the occupational shares in the public sector. These shares may be established by univariate regression or by keeping the share constant.

The nested model is developed from a model which includes all explanatory variables (the $X$-vector and the trend term). We have called this the base model with trend $(B M+)$. If the trend term is significant, this model is adopted. If not, a choice is made, by means of an F-test, between the model from which the trend term has been left out (only the $x$-vector remaining) and the one which holds no explanatory variables at all (neither the $x$ nor the trend term), only the sectoral constants remaining. These models are called, respectively, the base model (BM) and the sector-dummy model (SD).

So, the most extensive model is taken as the starting point. If the trend term is not significant it is the first to be removed from the equation, to avoid a non-significant trend influencing the forecasts. The second step is then to test whether the economic variables can explain the fluctuations in the occupational shares. If not, the sector-dummy model, that is, the sectoral average through time, is chosen.

At this spot we want to utter a warning about the effects of the method just presented to select an equation for individual occupations. In general, such 
'stepwise' procedures are based on a large number of regressors which by a criterion chosen beforehand (for instance the increase of $R^{2}$ ) are included in or excluded from the model. In the case of multicollinearity that procedure can lead to the inclusion of the 'wrong' variables in the regression equation, because the effects cannot be imputed unequivocally to the variables. With a stepwise method, the economic relevance of the explanatory variables is relaxed. The choice of variables is in fact made by a non-economic procedure. Moreover, the resulting estimators may be biased and the $t$-values computed need no longer follow a t-distribution ${ }^{12}$. Thus, in our case, the $t$-values for the exogenous variables in the base model are conditional upon the first test (the one on the trend term). Correction attempts land us in a complex statistical theory, a subject in its own right. For that reason we abandon the idea to correct for these effects, but we do keep them in mind for the analysis of the regression results in the next chapter.

Another result of the correlation between regressors is that the parameters not only indicate the effect of the corresponding variable but also absorb part of the influence of the other (correlated) regressors. To test whether a given factor influences the size of the variable to be explained, it is better to test the total effect (by an F-test) in the given situation than to examine the $t$-value for each separate variable. The above also points to the risks involved in removing from the model all exogenous variables with an absolute t-value of, say, less than 1 and then estimating the equation anew.

12. See, among others, Cassidy (1981). 


\section{ESTIMATION RESULTS}

\subsection{Overall results}

The occupational shares have been estimated separately for the two main sectors: agriculture and manufacturing industry, and tertiary and quaternary services. In the agricultural and industrial sector, model equations have been estimated for 38 occupational classes. The base model with trend term $(\mathrm{BM}+)$ was preferred in ten instances, the base model (BM) in six, and the sector-dummy model (SD mode1) in 22. In the service sector, 43 occupational classes have been estimated; this time, BM+ was selected ten times, BM seven times, and the SD model 26 times. Table 1 indicates the models chosen for each occupational class in the two main sectors, agriculture and manufacturing industry, and tertiary and quaternary services; occupations occurring in both sectors also figure twice in the table. In al1, 512 occupational shares were eligible for estimation ${ }^{13}$. The restriction that an occupation has to occur at least in two sectors of a main sector removed 45 occupational shares; another 44 shares in the public sector were also left out. So, in a11, 83 per cent of the occupational shares have been analyzed in this study.

The general tendency is for the sectoral constants to absorb much of the variance. That is evident not only from the number of times the SD model was preferred, but also from the fact that choosing a different model causes only a small increase of the adjusted $R^{2}$. Annex 3 gives a review of the adjusted $R^{2}$ of the model chosen (other than the SD model) and of the corresponding SD model. In the cases that the sector-dummy model was preferred, the occupational shares in sectoral employment are stable, or the differences among sectors cannot be explained by the present model.

Tables 1 through 4 of annex 4 present the results of the models finally chosen. The trend term assumes high values in some instances. The most striking feature is the trend-wise 20-percent drop estimated for clerical supervisors (occupational code 30). For this occupational class, the realizations of the shares display a steep drop for the years 1981 and

13. The criterion was that in that occupation in that sector, in one year a minimum of 1000 people were employed, or a minimum of 500 people throughout the years. 
1983, and recovery in 1985. The estimated shares, while not closely following the steep drop after 1981, do reproduce the turnabout after 1983. The actual great declines of 1981 and 1983 could have inspired the strongly negative trend estimated in the $(\mathrm{BM}+)$ model, but there is no risk of an exploding forecast in this case because the trend parameter has the negative sign. In agriculture and manufacturing industry such a risk does exist for the occupations of statisticians, mathematicians, systems analysts and related technicians (occupation code 08 ), managing and higher executive functions exclusive of public administration (occupation code 21), and chemical processers and related workers (occupation code 74 ), because of the size and the positive sign of the trend term. In the service sectors the same holds for the occupations of statisticians, mathematicians, systems analysts and related technicians (occupation code 08), economists (occupation code 09), and mail distribution clerks (occupation code 37 ). Comparing realized and estimated shares, we find with occupation 09 in one sector, and with occupation 74 in two sectors, a situation indicating a trend term that is, or threatens to become, dominating. For the time being there is no reason for any of the occupation categories mentioned to fear an explosion of the trend term, but there is certainly reason for future forecasts to keep alert to occupation shares that are systematically estimated too high.

The coefficient of the INVVA variable (investments related to value added) lies roughly between -1 and +1 . Extreme results in the service sectors refer to tailors, dressmakers, sewers, upholsterers and related workers (occupation code 79), and bricklayers, carpenters, and other construction workers (code 95). However, occupation 79 occurs in but two sectors (commerce and medical-veterinary). The series of the INVVA variable are nearly constant in both sectors, which carries the risk of multicollinearity with the sector dummies. Occupation 95 occurs in the two sectors just mentioned as well as in the 'other tertiary' and 'other quaternary' services. In particular other tertiary services display an all but constant development. Therefore, we have to be very careful in interpreting this coefficient. Besides, the fact must be taken into account that occupation 95 has only minimum representation in the service sectors (a maximum of 2,300 on a total of 169,000 in the occupation in 1985). The results for this occupation in agriculture and manufacturing industry show no extreme values of the estimated parameters. To our mind that is the more significant as the majority of employed persons are in this main sector. 
The elasticity of the employment share to the degree of capacity utilization (DCU) varies widely among occupations. In agriculture and manufacturing industry, the occupations of code 05: life scientists and related technicians, and of code 16: sculptors, painters, photographers, and related creative artists, show a very high elasticity. In the services, the same applies to code 08: statisticians, mathematicians, systems analysts and related technicians, code 30: clerical supervisors, and code 45: sales supervisors and buyers. The last two executive occupation classes refer clearly to the kind of overhead occupations for which, as pointed out in chapter 2, labour hoarding can be expected. However, the high, significant elasticity of the degree of capacity utilization (over 4) points in a different direction, namely to the sensitivity of these occupations to fluctuations in the degree of capacity utilization. That confrontation between theory and outcome gives rise to the observation that all these (shares of) occupations correspond to very small numbers of persons employed in the various sectors. The risk of serious measuring errors in the endogenous variable is very real in such cases. The other occupation classes, with a smaller estimated elasticity of the degree of capacity utilization (and for which the absolute t-value is larger than 1 ) display no unexpected signs.

An extreme value of the automation variable (AUT) is observed for the occupation class of life scientists and related technicians (code 05). However, this class occurs only in the agricultural sector and in the chemical and rubber industries. Moreover, automation staff have no significant share in agriculture; therefore, AUT has been set at 0 for this sector, and the coefficient refers only to the chemical and rubber industry. From the correlation matrix for this sector, the variables INVVA and AUT show strong negative correlation $(-.87)$. It is hard to say, therefore, whether AUT shows only the effects of automation or also those of investment and perhaps of the development trends. To verify this, additional regressions to test the stability of the automation parameter would be necessary. Such an exercise for all parameters and all occupations would exceed the scope of this report, however.

An occupation for which the explanation of the variance is exceptionally poor is that of transport and communications supervisors (occupation 35) in the main sector of agriculture and manufacturing industry. In annex 4, table 
1 , we find a adjusted $R^{2}$ of 0.06 . The occupation occurs in the sectors food, paper and printing, and chemical and rubber industry. The fact that the explanatory models do not explain the development of the shares suggests that the factors we have chosen do not explain the development of the dependent variable. Nor does the use of the sector-dummy model produce a significant improvement. That could imply either that we ought not to have pooled over sectors, or that the pattern of occupation 35 is influenced by factors not included in the analysis.

In conclusion, the estimated parameter values can be said to vary rather widely. However, we must keep in mind that the equation we have used is a reduced-form one, which makes it difficult to impute influences to one single factor. In a reduced-form equation, the parameter before a regressor represents several structural effects sharing the same variable as indicator. A clear example is the trend parameter, which absorbs, besides the sector-specific structural aspects and the effects that could not be distinguished explicitly, also part of the technological development. We have also seen that pooling by main sector leads to different model choices by occupation, which makes it seem unwise to pool over all sectors (that is to say, agriculture and manufacturing industry as well as tertiary and quaternary services).

\subsection{Discussion of the results on the level of occupational sectors}

This section discusses the results by one-digit occupational sector. We prefer this to separate discussion of every single occupation, which would produce a surfeit of information. Moreover, the sectoral treatment enables us to discuss the differences among occupational classes in one occupational sector.

Among the scientific and other experts, and artists (occupational sector $0 / 1$ ) we find important development trends for the occupations of code 08: statisticians, mathematicians, systems analysts and related technicians, and for economists (code 09). In the service sectors, occupation 08 is looked upon as an overhead occupation (significant negative sign of the degree of capacity utilization), while sculptors, painters, photographers and related creative artists (code 16) are positively correlated with the degree of capacity utilization. The latter may be due to the free-lance nature of some 
of the work in this occupational class, or the execution of ad hoc commissions.

Among the managing and higher executive functions (occupational sector 2), only occupational class 21 qualifies for estimation ${ }^{14}$, because occupational class 20 is represented only in the public sector. The sign of the occupation-degree variable corresponds - in agriculture and manufacturing industryto the fact that the occupation belongs to the overhead. In addition, in agriculture and manufacturing industry this occupational class displays a fast-growing trend, while in the service sector the trend term is not significant.

Among the clerical functions (occupational sector 3 ), occupations 30,31 and 35 can be considered overhead occupations. The remaining occupations in this sector are more of the operative kind. To find a positive elasticity to the degree of capacity utilization for occupation 30 (clerical supervisors) is remarkable, therefore. However, in most instances the SD-model has been chosen, so that the conclusion seems warranted that this occupational sector has a constant share in the various sectors of activity.

Among the commercial occupations (sector 4), insurance, real estate, securities and business services salesmen and auctioneers (occupation code 47) and salesmen, shop assistants and related workers (code 48) in agriculture and manufacturing industry display the same development trends. However, in this sector, estimations have been carried out for only half the occupational classes occurring. That makes statements about an entire occupational sector difficult to make. Once more, the high value of the capacity utilization coefficient for an executive occupation (occupation 45: sales supervisors and buyers) in the service sectors is striking.

Among the service functions (sector 5), an explanatory model has only been chosen for those service workers not elsewhere classified (code 59), although the shares of the other occupational classes are also observed to fluctuate. That may mean that the pooling within the main sectors

14. See section 4.1. Besides, for occupational class 21 the 1975 observations have not been included in the analysis, because for that year the values of the numbers of employed persons are not very reliable; see also CBS, AKT 1977 page 17. 
agriculture and manufacturing industry on the one hand and tertiary and quaternary sectors on the other is not warranted, or that there are explanatory variables not yet included in the model.

For the agrarian occupations (sector 6), only three regressions have been carried out, the sector-dumy model being chosen each time. The remaining three occupations are represented in one sector of industry only, and therefore have not been estimated.

The occupational sectors 7,8 and 9 comprise traditional, industrial, transport and related functions. With the exception of occupation 85 (electrical fitters and related electric and electronics workers), the occupational classes for which an explanatory model has been chosen are influenced negatively by the automation variable. For all occupations of code 8 (on the one-digit level) -the so-called craft occupations- a negative parameter has been estimated for INVVA, which means that capital is being substituted for labour. Among bricklayers, carpenters and other construction workers (occupation 95) we find opposite development trends in the two main sectors (the building sector comes under agriculture and manufacturing industry). Occupation 98 (transport equipment operators) is negatively affected by automation in agriculture and manufacturing industry. The fact is, however, that under this as well as a few other occupational codes in this sector of activity a number of 'rest' occupations have been classified, owing to which the clustering of occupational groups produces classes that are not very homogeneous. Perhaps that explains why for most other code- 9 occupations the sector-dummy model has been selected.

From the estimation results there appears to be no unequivocal relation to any one occupational sector. Nor does the division of the activity sectors between two main sectors reveal a pattern in the model choices. To give a general typology of the occupation pattern remains difficult, therefore. Nevertheless, in many instances the extension to an explanatory model means an improvement, in terms of the explanation of the development of the employment shares, on the sector-dummy model, which assumes constant occupation shares in each sector of activity. 
Table 1. Review of the models finally chosen, arranged by occupational codes.

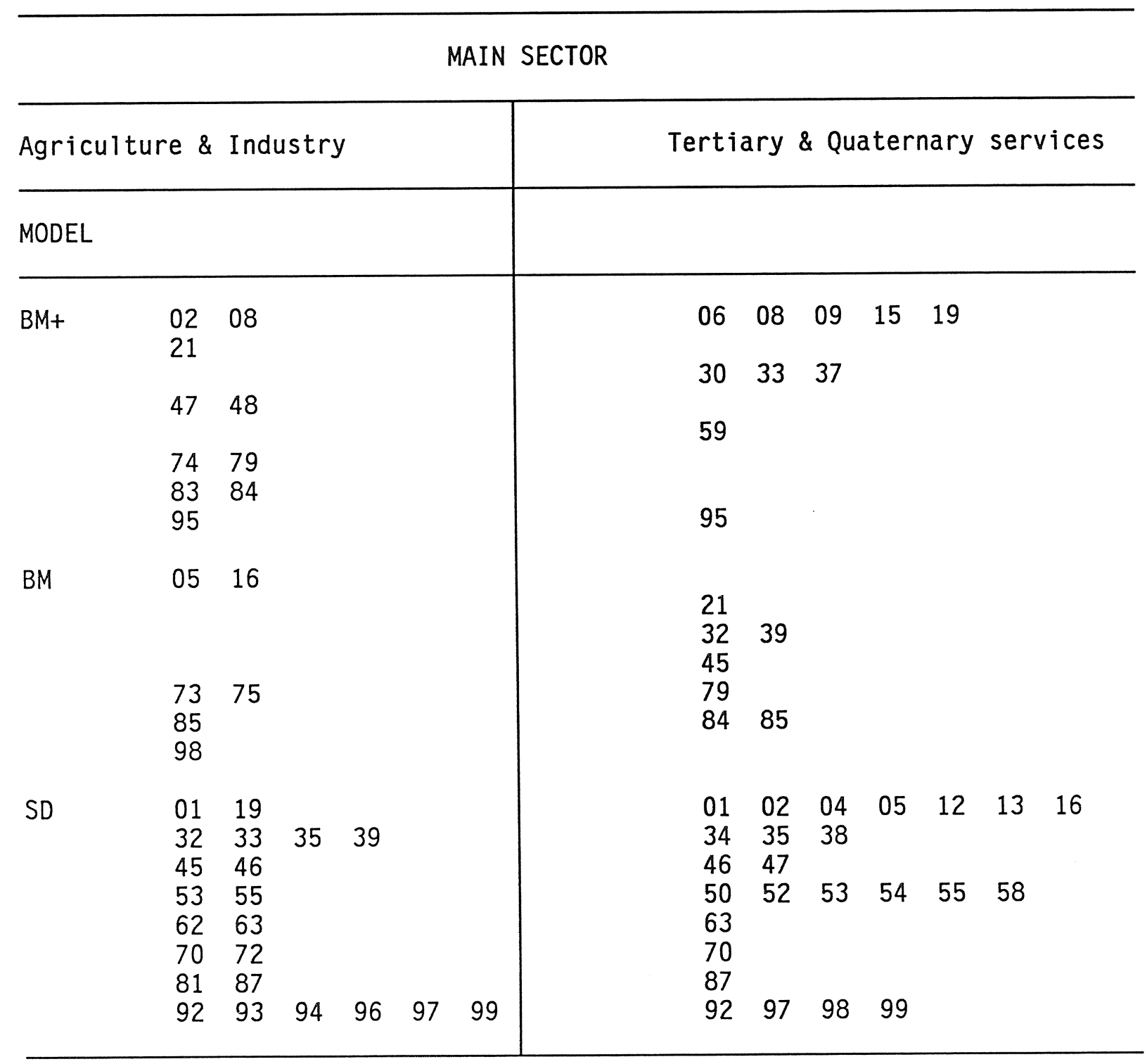

$\mathrm{BM+}=$ The base model with trend, that is, all exogenous variables including the trend term.

$\mathrm{BM}=$ The model with all exogenous variables exclusive of the trend term.

SD = The sector-dummy mode1. This model comprises no explanatory variables, but only a constant for each sector of activity.

Annex 1 relates the occupation codes to the names of occupations as employed also by the CBS. 


\section{CONCLUSIONS AND SUGGESTIONS FOR FURTHER RESEARCH}

This study represents an attempt to explain the development of the shares of occupational classes in the employment of sectors of activity with the help of a model containing, besides a trend term, some explanatory economic variables. Some factors have been mentioned that may influence the occupational pattern, out of which technological advance and sector-specific cyclical and structural effects have finally been included in the model.

The objective of this study was to investigate why the occupational pattern has developed as it has. To that end, the observations have been pooled over time and sectors of activity. That implies the assumption that the responses of an occupation to exogenous changes have the same effects in all sectors of activity, which does not prove, however, that the effects are indeed the same in all sectors or through time. In 40 per cent of the estimations carried out an explanatory model was preferred. Such a model is preferable to one that keeps the occupational shares constant or imposes a purely trendwise evolution, because it produces greater understanding of the processes that are decisive for the relative employment in a given occupation. The fact should be kept in mind, however, that the equation used is a reduced-form equation.

Because of limitations regarding the use of certain data sets, in the end fewer explanatory factors could be tested with the final model than had been initially envisaged. In the future, more attention might be given to the quality of the explanatory variables. The approximation of the part-time factor for one could be improved. A different investment variable might also be looked for, to reduce the risk of multicollinearity with the trend term or the sectoral constant. The impression is that multicollinearity has affected some of the estimations. That does not really jeopardize the forecasting of the shares (as long as the relation between the future values of the regressors is continued), but it does impede the interpretation of the parameters.

The econometric modeling of the evolution of sectoral employment by occupation is still at an infant stage. In this report, a model with constant elasticities has been used, no account being as yet taken of the fact that the shares add up to 1 . To some extent that has been done on 
purpose: when drawing up forecasts, we want to check how far the restrictions (by sector of activity) are binding. Moreover, the developing and application of a method taking account of these restrictions would have taken too much time. The final objective remains a model in which the restrictions are included in the estimation procedure and the parameters are susceptible to clear interpretation. 


\section{LITERATURE}

Ahamad, B., M. Blaug (eds.), The practice of manpower forecasting; a collection of case studies, Elsevier Scientific Publishing Company, Amsterdam, 1973.

ANTOS, De arbeidsmarkt naar sector, beroep en opleiding, 1983-1988, Verkennende studie van de werkgroep Anticiperend Opleidings- en Scholingsbeleid (ANTOS), Ministerie van Sociale Zaken en Werkgelegenheid, Den Haag, 1984 .

Bos, W., Overeengekomen jaarlijkse arbeidsduur, jaargemiddelde aantal banen en arbeidsvolume van werknemers, 1977-1986; methode en resultaten van een proefonderzoek, CBS Supplement bij de Sociaal-Economische Maandstatistiek, CBS, Voorburg, jaargang 1987 no. 5, pp. 9-20.

Broeder, G. den, J. de Voogd, De arbeidsmarkt van leerkrachten in het voortgezet onderwijs - Paper ten behoeve van de Onderwijsresearchdagen 1986 , Nederlands Economisch Instituut, Rotterdam, 1986.

Bureau of Labor Statistics, Employment Projections for 1995, U.S. Department of Labor, Bureau of Labor Statistics, Bulletin 2197, Washington, 1984.

Cassidy, H.J., Using Econometrics: A Beginner's Guide, Reston Publishing Company Inc. (A Prentice-Hal1 Company), Reston, 1981.

Centraal Bureau voor de Statistiek, Arbeidskrachtentellingen, CBS, Voorburg, $1975,1977,1979,1981,1983,1985$.

Centraal Planbureau, Centraal Economisch Plan 1987, CPB, 's-Gravenhage, 1987.

Centraal Planbureau en Sociaal en Cultureel Planbureau, Arbeidsvraag en -aanbod in de gezondheidszorg op de lange termijn, Centraal Planbureau, PKS-bulletin no. 5, 's-Gravenhage, 1984.

Doeringer, P.B., M.J. Piore, Internal Labor Markets and Manpower analysis, Heath Lexington Books, Lexington, 1971.

Grip, A. de, Interne arbeidsmarkttheorieën: Een overzicht, in: Maandschrift Economie, 1985, pp. 333-345.

Grip, A. de, J.A.M. Heijke, R.J.P. Dekker, L.F.M. Groot (ROA), De arbeidsmarkt naar beroep in 1992 en de positie van academici daarbinnen, Researchcentrum voor Onderwijs en Arbeidsmarkt, ROA-W-1987/1, Maastricht, 1987.

Hartog, H. den, B.A. Thoolen, Requirements and Supply of Qualified Manpower: Projections for the Netherlands (A tentative approach), Central Planning Bureau, Occasional Papers no.2, The Hague, 1971.

Heijke, J.A.M., Het Researchcentrum voor Onderwijs en Arbeidsmarkt, Researchcentrum voor Onderwijs en Arbeidsmarkt, ROA-rapport R-1986/1, Maastricht, 1986.

Hsiao, C., Analysis of panel data, Cambridge University Press, Cambridge, 1986. 
Judge, G.G, R.C. Hill, W.E. Griffiths, H. Lütkepoh1, T.C. Lee, Introduction to the theory and practice of econometrics, Wiley, New York, 1982.

Judge, G.G, W.E. Griffiths, R.C. Hil1, H. Lütkepoh1, T.C. Lee, The theory and practice of econometrics, Second Edition, Wiley, New York, 1985.

Klauder, W., Der methodische Ansatz des IAB zur längerfristigen Vorausschätzung des Arbeitsmarktes, in: Konzepte der Arbeitsmarkt- und Berufsforschung. Eine Forschungsinventur des IAB, Dieter Mertens, Institut für Arbeitsmarkt- und Berufsforschung der Bundesanstalt für Arbeit, Beitrag BeitrAB 70, Nürnberg, 1984, pp. 173-181.

Koning, J. de, Omvang en oorzaken van labour hoarding, Nederlands Economisch Instituut, Rotterdam, 1987.

Leser, L.E.V., Family Budget Data and Price-Elasticities of Demand, Review of Economic Studies, Vol. IX, 1941-1942, pp. 40-57.

NEI, Een verkenning van de arbeidsmarkt naar beroep en opleiding tot 1990 , Organisatie voor Strategisch Arbeidsmarktonderzoek, OSA-Werkdocument $\mathrm{nr}$. W17, Zoetermeer, 1986.

ROA, Naar een informatiesysteem onderwijs-arbeidsmarkt, onderzoeksprogramma 1988/1989, Researchcentrum voor Onderwijs en Arbeidsmarkt, ROA-rapport R-1988/1, Maastricht, 1988.

Spenner, K.I., The upgrading and downgrading of occupations, Review of Educational Research, vol. 55, no. 2, pp. 125-154, 1985.

Teulings, C.N, C.C. Koopmans, M.A. Koopmanschap, L. Vedder (SEO), Herverdeling van arbeid en Sociale Zekerheid, Ministerie van Sociale Zaken en Werkgelegenheid, Commissie Onderzoek Sociale Zekerheid, COSZ-reeks nr. 13, Den Haag, 1987. 
$-25-$

ANNEX I : LIST OF OCCUPATION CODES AND CORRESPONDING NAMES

ANNEX II : DIVISION OF SECTORS OF ACTIVITY AND SOURCES OF VARIABLES

ANNEX III : DIFFERENCES BETWEEN ADJUSTED $R^{2}$ FOR THE CHOSEN MODEL AND THE SECTOR-DUMMY MODEL

ANNEX IV : ESTIMATION RESULTS 
ANNEX 1: LIST OF OCCUPATION CODES AND CORRESPONDING NAMES

\section{CODE OCCUPATION}

01 Physical scientists and related technicians.

02/03 Architects, engineers and related technicians.

04 Aircraft and ships' officers.

05 Life scientists and related technicians.

06/07 Medical, dental, veterinary and related workers.

08 Statisticians, mathematicians, systems analysts and related technicians.

09 Economists.

11 Accountants.

12 Jurists.

13 Teachers.

14 Workers in religion.

15 Authors, journalists and related writers.

16 Sculptors, painters, photographers and related creative artists.

17 Composers and performing artists.

18 Athletes, sportsmen and related workers.

19 Professional, technical and related workers N.E.C.

20 Legislative officials and government administrators.

21 Managing and higher executive functions exclusive of public administration.

$30 \quad$ Clerical supervisors.

31 Government executive officials.

32 Stenographers, typists and card- and tape-punching machine operators.

33 Bookkeepers, cashiers and related workers.

34 Computing machine operators.

35 Transport and communications supervisors.

36 Transport conductors. 
37 Mail distribution clerks.

38 Telephone and telegraph operators.

39 Clerical and related workers N.E.C.

40 Managers (wholesale).

41 Managers (retail trade).

42 Working proprietors (wholesale).

43+44 Shopkeepers; street vendors.

45 Sales supervisors and buyers.

46 Technical salesmen, commercial travellers and manufacturers' agents.

47 Insurance, real estate, securities and business services, salesmen, and auctioneers.

48 Salesmen, shop assistants and related workers.

49 Sales workers N.E.C.

50 Managers (catering and lodging services).

51 Working proprietors (catering and lodging services).

52 Housekeeping and related service supervisors.

53 Cooks, waiters, bartenders and related workers.

54 Maids and related housekeeping workers N.E.C.

55 Building caretakers, charworkers, cleaners and related workers.

56 Launderers, dry-cleaners and pressers.

57 Hairdressers, barbers, beauticians related workers.

58 Protective service workers.

59 Service workers N.E.C.

60 Farm managers and supervisors.

61 Farmers.

62 Agricultural and animal husbandry workers.

63 Forestry workers.

64 Fishermen, hunters and related workers.

70 Production supervisors and general foremen. 
71 Miners, quarrymen, well drillers and related workers.

72 Metal processors.

73 Wood preparation workers and paper makers.

74 Chemical processers and related workers.

75 Spinners, weavers, knitters, dyers and related workers.

76 Tanners, fellmongers and pelt dressers.

77 Food and beverage processers.

78 Tobacco preparers and tobacco-product makers.

79 Tailors, dressmakers, sewers, upholsterers and related workers.

80 Shoemakers, and leather goods makers.

81 Cabinetmakers, woodworkers and related workers.

82 Stone cutters and carvers.

83 Blacksmiths, toolmakers, and machine tool operators.

84 Machinery fitters, machine assemblers and precision-instrument makers (except electrical).

85 Electrical fitters and related electric and electronics workers.

86 Broadcasting station and sound equipment operators and cinema projectionists.

87 Plumbers, welders, sheet metal and structural metal preparers and erectors.

88 Jewellery and precious metal workers.

89 Glass formers, potters and related workers.

90 Rubber and plastics product makers.

91 Paper and paperboard products makers.

92 Printers and related workers.

93 Painters.

94 Production and related workers N.E.C.

95 Bricklayers, carpenters and other construction workers.

96 Stationary engine and related equipment operators. 
97 Material handling and related equipment operators, dockers and freight handlers.

98 Transport equipment operators.

99 Labourers N.E.C. 
ANNEX II: DIVISION OF SECTORS OF ACTIVITY AND SOURCES OF VARIABLES

\section{AGRICULTURE \& MANUFACTURING INDUSTRY}

Agriculture, fishing, forestry

Manufacture of foodstuffs, beverages,

tobacco products

Manufacture of textiles, wearing apparel,

footwear and other leather products

Manufacture of wood and building materials

and glass products

Chemical industry and manufacture of rubber

and plastic products

Manufacture of paper and printing and publishing

industries

Basic metal industries

Manufacture of metal products, mechanical and

instrument engineering

Electrical engineering

Manufacture of transport equipment

Petroleum industry

Mining and quarrying

Electricity, gas and water

Construction and ownership of dwellings

\section{TERTIARY \& QUATERNARY SERVICES}

Trade (wholesale and retail)

Sea and air transport

Transport, storage and communication

Banking and insurances

Other private services

Medical and veterinary services

other public services

GOVERNMENT

Public administration and education
CBS-SBI code

0

20-21

$22-24$

25,32

26-27

29-31

33

$34,35,38,39$

36

37

28

1

4

5,83
61-66

73,75

$71,72,74,76,77$

81,82

$67,68,84,85,98,99$

93

$91,94-96,97$

90,92 
Sources of the variables

The definitions of the variables can be found back in the main text. At this place the sources are indicated of the data used to construct the variables.

\section{REGRESSORS:}

Degree of capacity utilization: the value-added figures are from the CPB. The basis is gross value added, 1980 market prices.

Investments: the investment figures have been obtained from the CPB, and refer to investments in works of civil engineering, equipment and means of transportation, at 1980 prices. For the sectors banks and insurances, other tertiary services, medical and veterinary services and the other quaternary services, no separate investment figures were known. Therefore, to each of these four sectors equal proportions (one fourth) have been allocated.

Automation: for sectors lacking a significant share of occupational class 08 , this variable has been set at 0 in the final equation ( 8 ).

Number of companies: this figure is based for 1975 and 1977 on the Social Statistical Monthly of the CBS. In 1978 another methodology was adopted, which causes a breach in the series. In the event, these data have not been included in the estimations.

REGRESSAND:

The occupation shares and the part-time factor (average worktime by occupational class and by sector of activity) have been derived from the Labour-Force Censuses of the CBS. 
ANNEX III: DIFFERENCES BETWEEN ADJUSTED $R^{2}$ FOR THE CHOSEN MODEL AND THE SECTOR-DUMMY MODEL

AGRICULTURE \& MANUFACTURING INDUSTRY

\begin{tabular}{|c|c|c|c|c|}
\hline $\begin{array}{l}\text { OCCUPATION } \\
\text { CODE }\end{array}$ & $\operatorname{adj} \cdot R^{2}$ & $\operatorname{adj} . R^{2} S D$ & $\mathrm{adj}$ & $\operatorname{adj} \cdot R^{2} S D$ \\
\hline $\begin{array}{l}02 \\
05\end{array}$ & $\begin{array}{l}.97 \\
.80\end{array}$ & $\begin{array}{l}.96 \\
.55\end{array}$ & & \\
\hline 06 & & & .99 & .99 \\
\hline 08 & .88 & .88 & .95 & .84 \\
\hline 09 & & & .82 & .71 \\
\hline 15 & & & .98 & $<0$ \\
\hline 16 & .70 & .38 & & \\
\hline 19 & & & .98 & .98 \\
\hline 21 & .86 & .54 & .85 & .82 \\
\hline 30 & & & .85 & .75 \\
\hline 32 & & & .97 & .96 \\
\hline 33 & & & .99 & .99 \\
\hline 37 & & & .99 & .99 \\
\hline 39 & & & .97 & .95 \\
\hline 45 & & & .99 & .96 \\
\hline 47 & .87 & .53 & & \\
\hline 48 & .94 & .93 & & \\
\hline 59 & & & .99 & .99 \\
\hline 73 & .95 & .90 & & \\
\hline 74 & . 97 & .96 & & \\
\hline 75 & .97 & .93 & & \\
\hline 79 & .99 & .99 & .91 & .69 \\
\hline 83 & .96 & .88 & & \\
\hline 84 & .98 & .98 & .97 & .95 \\
\hline 85 & .99 & .99 & .98 & .98 \\
\hline 95 & .99 & .99 & .66 & .38 \\
\hline 98 & .96 & .96 & & \\
\hline
\end{tabular}

\section{TERTIARY \& QUATERNARY} SERVICES

$d j \cdot R^{2} \quad \operatorname{adj} \cdot R^{2} S D$

(1)


ANNEX IV: ESTIMATION RESULTS TABLE 1-4

Table 1. Occupations occurring in both main sectors

\begin{tabular}{|c|c|c|c|c|c|c|c|}
\hline \multicolumn{8}{|c|}{ AGRICULTURE/MANUFACTURING INDUSTRY } \\
\hline $\begin{array}{l}\text { Occupa- } \\
\text { tional } \\
\text { code }\end{array}$ & $\begin{array}{l}\text { Number } \\
\text { of } \\
\text { sectors }\end{array}$ & $\begin{array}{l}\text { Chosen } \\
\text { model }\end{array}$ & INVVA & $\mathrm{DCU}$ & AUT & TRND & $\bar{R}^{2}$ \\
\hline 01 & 5 & SD & & & & & .95 \\
\hline 02 & 13 & $\mathrm{BM}+$ & $\begin{array}{l}.16236 \\
(1.68)\end{array}$ & $i^{44231}$ & $\begin{array}{r}-.01303 \\
(.21)\end{array}$ & $\begin{array}{l}.03556 \\
(4.70)\end{array}$ & .97 \\
\hline 05 & 2 & BM & $\begin{array}{r}1.28363 \\
(1.72)\end{array}$ & $\begin{array}{r}4.72950 \\
(1.56)\end{array}$ & $\begin{array}{r}1.31844 \\
(3.09)\end{array}$ & & .80 \\
\hline 08 & 5 & $\mathrm{BM}+$ & $\begin{array}{r}-.79608 \\
(1.41)\end{array}$ & $\begin{array}{r}-.72678 \\
(.37)\end{array}$ & --- & $\begin{array}{l}10209 \\
(2.98)\end{array}$ & .88 \\
\hline 16 & 2 & BM & $\begin{array}{r}-1.69193 \\
(1.72)\end{array}$ & $\begin{array}{r}3.64911 \\
(2.34)\end{array}$ & $\begin{array}{l}.14332 \\
(.84)\end{array}$ & & .70 \\
\hline 19 & 3 & SD & & & & & .63 \\
\hline 21 & 13 & $\mathrm{BM}+$ & $\begin{array}{r}-.56059 \\
(2.50)\end{array}$ & $\begin{array}{r}-1.58844 \\
(1.73)\end{array}$ & $\begin{array}{r}-.15795 \\
(1.68)\end{array}$ & $\begin{array}{l}13596 \\
(10.02)\end{array}$ & .86 \\
\hline 32 & 10 & SD & & & & & .70 \\
\hline 33 & 12 & SD & & & & & .93 \\
\hline 35 & 3 & SD & & & & & .06 \\
\hline 39 & 14 & SD & & & & & .94 \\
\hline 45 & 6 & SD & & & & & .80 \\
\hline 46 & 8 & SD & & & & & .92 \\
\hline 47 & 2 & $\mathrm{BM}+$ & $\begin{array}{r}1.08823 \\
(2.04)\end{array}$ & $\begin{array}{r}1.48112 \\
(.73)\end{array}$ & $\begin{array}{r}-.28971 \\
(1.69)\end{array}$ & $\begin{array}{l}.08673 \\
(3.93)\end{array}$ & .87 \\
\hline 48 & 7 & $\mathrm{BM}+$ & $i^{.66181}$ & $\begin{array}{r}-1.75246 \\
(.84)\end{array}$ & $\begin{array}{l}.03171 \\
(.19)\end{array}$ & $\begin{array}{l}.08780 \\
(3.15)\end{array}$ & .94 \\
\hline 53 & 5 & SD & & & & & .67 \\
\hline 55 & 7 & SD & & & & & .46 \\
\hline 62 & 3 & SD & & & & & .99 \\
\hline 70 & 11 & SD & & & & & .63 \\
\hline 79 & 3 & $\mathrm{BM}+$ & $\begin{array}{r}-.06370 \\
(.31)\end{array}$ & $\begin{array}{r}-.90510 \\
(1.97)\end{array}$ & $\begin{array}{r}.05013 \\
(.24)\end{array}$ & $\begin{array}{l}.02502 \\
(2.60)\end{array}$ & .99 \\
\hline 84 & 13 & $\mathrm{BM}+$ & $\begin{array}{r}-.21137 \\
(1.57)\end{array}$ & $\begin{array}{r}-.36274 \\
(.78)\end{array}$ & $\begin{array}{r}-.18185 \\
(3.02)\end{array}$ & $\begin{array}{l}.01606 \\
(2.02)\end{array}$ & .98 \\
\hline 85 & 10 & $\mathrm{BM}$ & $\begin{array}{r}-.08747 \\
(.86)\end{array}$ & $\begin{array}{r}.26804 \\
(.57)\end{array}$ & $\begin{array}{l}.15459 \\
(3.07)\end{array}$ & & .99 \\
\hline 87 & 7 & SD & & & & & .98 \\
\hline 92 & 3 & SD & & & & & .99 \\
\hline 95 & 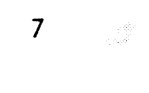 & $\mathrm{BM}+$ & $\begin{array}{l}.28079 \\
(2.09)\end{array}$ & $\begin{array}{r}1.08272 \\
(1.34)\end{array}$ & $\begin{array}{l}.17254 \\
(.73)\end{array}$ & $\begin{array}{r}-.01657 \\
(2.53)\end{array}$ & 99 \\
\hline 97 & 13 & SD & & & & & .98 \\
\hline 98 & 8 & $B M$ & $\begin{array}{r}-.30049 \\
(1.39)\end{array}$ & $\begin{array}{r}1.04235 \\
(1.24)\end{array}$ & $\begin{array}{r}-.25644 \\
(2.47)\end{array}$ & & 96 \\
\hline 99 & 8 & SD & & & & & .76 \\
\hline
\end{tabular}


$-34-$

Table 2. Occupations occurring in both main sectors

\begin{tabular}{|c|c|c|c|c|c|c|c|}
\hline & & TIARY/QU & ATERNARY SE & ERVICES & & & \\
\hline $\begin{array}{l}\text { Occupa- } \\
\text { tional } \\
\text { code }\end{array}$ & $\begin{array}{l}\text { Number } \\
\text { of } \\
\text { sectors }\end{array}$ & $\begin{array}{l}\text { Chosen } \\
\text { model }\end{array}$ & INVVA & DCU & AUT & TRND & $\bar{R}^{2}$ \\
\hline 01 & 3 & SD & & & & & .78 \\
\hline 02 & 7 & SD & & & & & .98 \\
\hline 05 & 3 & SD & & & & & .97 \\
\hline 08 & 6 & $B M+$ & $\begin{array}{l}.81324 \\
(1.05)\end{array}$ & $\begin{array}{r}-3.56947 \\
(1.60)\end{array}$ & --- & $\begin{array}{l}14623 \\
(7.39)\end{array}$ & .95 \\
\hline 16 & 3 & SD & & & & & .90 \\
\hline 19 & 6 & $\mathrm{BM}+$ & $\begin{array}{r}-.17827 \\
(.27)\end{array}$ & $\begin{array}{r}-1.67838 \\
(.72)\end{array}$ & $\begin{array}{r}-.16185 \\
(1.57)\end{array}$ & $\begin{array}{l}.04836 \\
(2.77)\end{array}$ & .98 \\
\hline 21 & 7 & $B M$ & $\begin{array}{r}-.61460 \\
(.92)\end{array}$ & $i^{.03180}$ & $\begin{array}{l}.33267 \\
(2.67)\end{array}$ & & .85 \\
\hline 32 & 7 & BM & $\begin{array}{l}.66299 \\
(2.48)\end{array}$ & $\begin{array}{r}1.25219 \\
(1.66)\end{array}$ & $\begin{array}{r}-.02016 \\
(.52)\end{array}$ & & .97 \\
\hline 33 & 7 & $\mathrm{BM}+$ & $\begin{array}{r}-.09996 \\
(.42)\end{array}$ & $\begin{array}{l}.62585 \\
(1.12)\end{array}$ & $\begin{array}{r}-.08726 \\
(1.66)\end{array}$ & $\begin{array}{l}.02929 \\
(2.96)\end{array}$ & .99 \\
\hline 35 & 3 & SD & & & & & .98 \\
\hline 39 & 7 & BM & $\begin{array}{l}.53323 \\
(2.75)\end{array}$ & $\begin{array}{r}-.31436 \\
(.50)\end{array}$ & $\begin{array}{r}-.09217 \\
(2.15)\end{array}$ & & .97 \\
\hline 45 & 2 & BM & $\begin{array}{r}-.97779 \\
(2.12)\end{array}$ & $\begin{array}{r}4.52699 \\
(4.89)\end{array}$ & $i^{.08421}(.87)$ & & .99 \\
\hline 46 & 2 & SD & & & & & .98 \\
\hline 47 & 3 & SD & & & & & .99 \\
\hline 48 & 3 & SD & & & & & .99 \\
\hline 53 & 7 & SD & & & & & .99 \\
\hline 55 & 6 & SD & & & & & .96 \\
\hline 62 & 4 & SD & & & & & .92 \\
\hline 70 & 6 & SD & & & & & .74 \\
\hline 79 & 2 & $B M$ & $\begin{array}{r}5.26445 \\
(5.16)\end{array}$ & $\begin{array}{r}-2.38129 \\
(1.13)\end{array}$ & $\begin{array}{r}-.13323 \\
(.73)\end{array}$ & & .91 \\
\hline 84 & 6 & BM & $\begin{array}{r}-.66297 \\
(1.44)\end{array}$ & $\begin{array}{r}1.45206 \\
(1.10)\end{array}$ & $\begin{array}{r}-.27873 \\
(3.60)\end{array}$ & & .97 \\
\hline 85 & 6 & BM & $\begin{array}{r}-.08356 \\
(.32)\end{array}$ & $i^{21401}(.20)$ & $\begin{array}{l}.14717 \\
(1.64)\end{array}$ & & .98 \\
\hline 87 & 3 & SD & & & & & .86 \\
\hline 92 & 3 & SD & & & & & .67 \\
\hline 95 & 4 & $\mathrm{BM}+$ & $\begin{array}{r}5.26997 \\
(3.54)\end{array}$ & $\begin{array}{r}2.54923 \\
(.96)\end{array}$ & $\begin{array}{r}-.00148 \\
(.01)\end{array}$ & $\begin{array}{l}.07950 \\
(2.25)\end{array}$ & .66 \\
\hline 97 & 5 & SD & & & & & .98 \\
\hline 98 & 7 & SD & & & & & .99 \\
\hline 99 & 3 & SD & & & & & .92 \\
\hline
\end{tabular}


Table 3. Occupations occurring in agriculture and manufacturing industries

\begin{tabular}{|c|c|c|c|c|c|c|c|}
\hline $\begin{array}{l}\text { Occupa- } \\
\text { tional } \\
\text { code }\end{array}$ & $\begin{array}{l}\text { Number } \\
\text { of } \\
\text { sectors }\end{array}$ & $\begin{array}{l}\text { Chosen } \\
\text { model }\end{array}$ & INVVA & DCU & AUT & TRND & $\overline{\mathrm{R}}^{2}$ \\
\hline 63 & 3 & SD & & & & & .83 \\
\hline 72 & 3 & SD & & & & & .96 \\
\hline 73 & 2 & BM & $\begin{array}{r}-1.36791 \\
(3.30)\end{array}$ & $\begin{array}{r}-.18870 \\
(.20)\end{array}$ & $\begin{array}{r}-.11594 \\
(1.12)\end{array}$ & & .95 \\
\hline 74 & 4 & $\mathrm{BM}+$ & $\begin{array}{r}-.24316 \\
(1.06)\end{array}$ & $\begin{array}{r}-.99407 \\
(.85)\end{array}$ & $\begin{array}{r}-.51692 \\
(2.03)\end{array}$ & $\begin{array}{l}.11426 \\
(2.66)\end{array}$ & .97 \\
\hline 75 & 2 & $B M$ & $\begin{array}{r}1.72107 \\
(2.19)\end{array}$ & $\begin{array}{r}2.40453 \\
(1.80)\end{array}$ & $\begin{array}{r}-.18600 \\
(.38)\end{array}$ & & .97 \\
\hline 81 & 3 & SD & & & & & .99 \\
\hline 83 & 5 & $\mathrm{BM}+$ & $\begin{array}{r}-.00733 \\
(.03)\end{array}$ & $\begin{array}{r}-.48804 \\
(.77)\end{array}$ & $\begin{array}{r}-.19305 \\
(2.51)\end{array}$ & $\begin{array}{r}-.07647 \\
(7.61)\end{array}$ & .96 \\
\hline 93 & 5 & SD & & & & & .98 \\
\hline 94 & 6 & SD & & & & & .95 \\
\hline 96 & 2 & SD & & & & & .84 \\
\hline
\end{tabular}


Table 4. Occupations occurring in tertiary and quaternary services

\begin{tabular}{|c|c|c|c|c|c|c|c|}
\hline $\begin{array}{l}\text { Occupa- } \\
\text { tional } \\
\text { code }\end{array}$ & $\begin{array}{l}\text { Number } \\
\text { of } \\
\text { sectors }\end{array}$ & $\begin{array}{l}\text { Chosen } \\
\text { model }\end{array}$ & INVVA & DCU & AUT & TRND & $\overline{\mathrm{R}}^{2}$ \\
\hline 04 & 2 & SD & & & & & .99 \\
\hline 06 & 4 & $\mathrm{BM}+$ & $\left..^{95851} . .65\right)$ & $\begin{array}{l}.87082 \\
(.22)\end{array}$ & $\begin{array}{r}-.00155 \\
(.02)\end{array}$ & $\begin{array}{l}.04390 \\
(2.23)\end{array}$ & .99 \\
\hline 09 & 4 & $\mathrm{BM}+$ & $\begin{array}{r}-.85374 \\
(.53)\end{array}$ & $\begin{array}{r}2.39244 \\
(.71)\end{array}$ & $\begin{array}{r}-19917 \\
(.58)\end{array}$ & $\begin{array}{l}15676 \\
(2.74)\end{array}$ & .82 \\
\hline 12 & 3 & SD & & & & & .89 \\
\hline 13 & 4 & SD & & & & & .95 \\
\hline 15 & 2 & $\mathrm{BM}+$ & $\begin{array}{l}.89968 \\
(3.69)\end{array}$ & $\begin{array}{r}1.48523 \\
(.94)\end{array}$ & $\begin{array}{l}.22641 \\
(2.02)\end{array}$ & $\begin{array}{l}.06375 \\
(2.86)\end{array}$ & .98 \\
\hline 30 & 5 & $\mathrm{BM}+$ & $\begin{array}{r}1.90599 \\
(1.50)\end{array}$ & $\begin{array}{r}4.15812 \\
(.87)\end{array}$ & $\begin{array}{l}.74824 \\
(2.01)\end{array}$ & $\begin{array}{r}-.20398 \\
(3.22)\end{array}$ & .85 \\
\hline 34 & 4 & SD & & & & & .85 \\
\hline 37 & 3 & $\mathrm{BM}+$ & $\begin{array}{r}1.52181 \\
(2.21)\end{array}$ & $\begin{array}{r}.73879 \\
(.76)\end{array}$ & $i_{(.05942}^{.60)}$ & $\begin{array}{l}12225 \\
(2.26)\end{array}$ & .99 \\
\hline 38 & 6 & SD & & & & & .94 \\
\hline 50 & 2 & SD & & & & & .71 \\
\hline 52 & 3 & SD & & & & & .76 \\
\hline 54 & 5 & SD & & & & & .95 \\
\hline 58 & 3 & SD & & & & & .41 \\
\hline 59 & 4 & $\mathrm{BM+}$ & $i^{.40002}$ & $\begin{array}{r}-1.58207 \\
(.58)\end{array}$ & $\begin{array}{r}-.04006 \\
(.73)\end{array}$ & $\begin{array}{r}-.03381 \\
(2.46)\end{array}$ & .99 \\
\hline
\end{tabular}

